\title{
Determining the Views of Teachers on the Transition to Digital Transformation in Education During the Pandemic Process: A Case Study
}

\author{
Ezgi Pelin YILDIZ ${ }^{1}$ \\ ${ }^{1}$ Kafkas University Kazım Karabekir Vocational School of Technical Sciences Department of Computer \\ Programming, KARS, Turkey \\ Correspondence: Ezgi Pelin YILDIZ, Kafkas University Kazım Karabekir Vocational School of Technical \\ Sciences Department of Computer Programming, KARS, Turkey.
}

Received: August 10, 2021

Accepted: September 23, $2021 \quad$ Online Published: October 24, 2021

doi:10.5539/jel.v10n6p92

URL: https://doi.org/10.5539/jel.v10n6p92

This study was presented orally at the $10^{\text {th }}$ International Conference on Education (ICED-2021) Girne in Cyprus.

\begin{abstract}
In today's world, where people live together with technology, digitalisation is increasingly taking its place as an indispensable part of our lives. However, rapid developments and changes in technology have led to compulsory digitalisation processes in all sectors. In addition to the pandemic process, digital transformation has now become a necessity. The pandemic threat faced by countries has affected many sectors, especially the education sector. In this context, it has become a necessity to take the necessary measures in the education sector, which affects a large audience. The first of these measures is the emergency distance education plan. Undoubtedly, it is clear that every stakeholder of education is affected by the emergency distance education plan that has come with the pandemic process. The most important of these stakeholders are undoubtedly teachers. In light of all this information, this study aimed to determine the views of teachers on the transition to digital transformation in education during the pandemic process. The research is an example of a qualitative case study. A semi-structured interview form was prepared by the researcher to determine the teachers' views on the subject. Data were collected using the semi-structured interview form. As a result, the teachers emphasised that they see the transition to digital transformation in education as a necessity, especially during the pandemic process, but they need more in-service training to keep up with this transformation.
\end{abstract}

Keywords: Dijital transformation, emergency distance education plan, pandemic process, view of the teachers

\section{Introduction}

As of December 2019, a virus that caused serious infections and fatal outcomes was encountered in Wuhan, China. This virus spread rapidly to other countries and, as a result, a global pandemic was declared by the World Health Organisation (2020). This disease, which increased rapidly among countries in a short time, was termed as the COVID-19 disease, and brought along social concerns worldwide with positive cases and deaths (Lin, 2020).

The pandemic threat faced by countries has affected many sectors, especially the health sector (Macit, 2020; Telli-Yamamoto \& Altun, 2020; Ustun \& Ozciftci, 2020), as well as the education sector. In this context, it has become a necessity to take the necessary measures in the education sector, which affects a large audience. The first of these measures is the 'emergency distance education plan'. In this context, distance education activities were started in primary and secondary education institutions in Turkey as of 23 March 2020, within the scope of preventing contagion by ensuring that the young and children population stay at home during the process. In the process, the infrastructure studies of the Educational Information Network (EBA) platform for educational activities were completed and students were integrated with education through internet technologies and TV broadcasts for all grade levels (MEB, 2020a).

In addition to the pandemic, support was received from digital platforms in this process. One of these platforms was Zoom, and it has been one of the most preferred course tools in the process (Degges-White, 2020; 
Wiederhold, 2020). According to the research report of the Teacher Academy Foundation on the daily practices, perceptions and training needs during the pandemic period (2020), the most used digital tool by teachers during the distance education period has been Zoom. It has been determined that the other digital tools were EBA, Skype, Adobe Connect and YouTube. At this point, both teachers and education experts were asked about the reasons why Zoom is the most used digital tool by them. The user-friendly interface, free session for a certain period of time, easy access to screen sharing, correspondence and the ability to see a large number of participants in frames at the same time are among the factors.

Distance education is one of the most popular education approaches of recent times, which eliminates time and space limitations through a wide variety of teaching methods and techniques, enabling the execution of educational activities. Examining the historical development process shows that distance education, which has proven itself in the process until today, has become an essential part of education and not just a tool in time (Bozkurt, 2019). In this context, distance education is not just a single structure or a single pedagogical approach (O'Keefe et al., 2020). On the contrary, it is a system approach that consists of different learning materials within the framework of certain purposes and scopes (Moore \& Kearsley, 2012).

With the pandemic process, distance education has gained a different dimension. This form of education, which is called distance education during the pandemic process, has been conceptualised as 'Emergency Distance Education' in the literature. Emergency distance learning is defined as education activities offered to support students socially, emotionally, cognitively and physically when they cannot access the education system due to extraordinary conditions (Nicolai \& Triplehorn, 2003; Sinclair, 2002). During the pandemic period, institutions transitioned to emergency distance education applications without a preparation process. Therefore, how the education and training activities progressed during the pandemic process, what happened during the process and the effectiveness of the reshaped educational practices have been a matter of curiosity (Soylemez, 2020). In this context, distance education in the context of COVID-19 has been found to be worth examining for many researchers during this epidemic period that has affected the whole world, and different studies have been carried out on this subject in this short period of time.

The most important point that distinguishes emergency distance education from e-learning is that the transition to distance education is presented as a temporary solution until normalisation occurs, rather than being permanent, and this transition process has been put into practice very quickly. For these reasons, it is not always possible to benefit from some advantages such as flexible learning, sensitivity to learner speed, presentation of learner-specific feedback and modality provided by e-learning in emergency distance education (Hodges et al., 2020).

Undoubtedly, it is clear that every stakeholder of education is affected by the emergency distance education plan that has come with the pandemic process. One of the stakeholders is teachers/lecturers. In this process, the effects of which are still ongoing and unknown for how long it will take, it is considered important to determine the opinions of teachers working in an applied field such as the teaching profession (Duban \& Sen, 2020; Karakus, Ucuzsatar, Karacaoglu, Esendemir, \& Bayraktar, 2020). Determining the opinions of teachers, who are accepted as one of the basic elements of education, in the 'New World Order' came with the pandemic process and the teacher candidates who will be the teachers of the future are necessary for the healthy functioning of the system (Ari \& Kanat, 2020).

In light of all this information, this study aimed to determining the views of teachers on the transition to digital transformation in education during the pandemic process. This research, which is structured as a qualitative case study, will reveal the deficiencies of the emergency distance education planning followed during the pandemic process and in this direction the measures that can be taken for the future process will be discussed. In this context, it is clear that this direction of research will guide the literature and future research.

\section{Conceptual Framework}

The research studies in the literature are examined within the scope of determining the opinions of teachers about the transition to digital transformation in education during the pandemic process.

Kavuk and Demirtas (2020), in their research, discussed the difficulties experienced by teachers in the distance education during the COVID-19 pandemic. The study was carried out with the phenomenology pattern, one of the qualitative research methods. A total of 43 teachers constituted the study group of the research. Data were collected using a semi-structured interview form. According to the results obtained in the research, the teachers stated that the main difficulties they experienced were the insufficiencies of students in terms of technological tools and the access to Internet connection problems for distance learning. In addition, inequality of opportunity, inadequacy of the EBA system, students' inability to actively participate in the course, technical problems and 
excessive involvement of parents in the process were other important problems.

Other literature studies also support this result; they stated that Internet access is a very common problem in distance education (Sercemeli \& Kurnaz, 2020). The decrease in face-to-face communication and interaction is among the limitations of distance education. It is stated that Internet access is a very common problem in distance education (Altun Ekiz, 2020; Karakus et al., 2020). However, the lack of access to the technologies used in the process, the lack of technology and Internet infrastructure and reasons such as low attitudes and motivations can negatively affect the quality of the distance education process (Batdal Karaduman, Aksak Ertas, \& Duran Baytar, 2021). Basaran, Dogan, Karaoglu and Sahin (2020) listed the problems experienced during the process as limited interaction, students' inability to participate actively in the lesson and that distance education is not suitable for individual differences and technical problems experienced.

Turkan, Leblebici and Onal (2020), in their study, detected the reflections of the COVID-19 pandemic period on undergraduate education through opinions of teacher candidates. The participant group consisted of 27 teacher candidates. As a result, it has been determined that the most important problems of teachers regarding the compulsory distance education process that come with the pandemic process are the difficulties experienced in measurement and evaluation.

In a similar study, Toprak, Bayraktar and Ozyllmaz (2020) discussed the issue of digital transformation in higher education with the COVID-19 pandemic. In this research, a model compatible with the new generation digital university concept was developed. The digital readiness of universities has been evaluated through web pages. As a result, the digital university road map has been proposed.

\section{Research Method}

The research is an example of a qualitative case study. A case study is an in-depth study of a particular research problem rather than a sweeping statistical survey or comprehensive comparative inquiry. The case study research design is also useful for testing whether a specific theory and model actually applies to the phenomena in the real world (Cresswell \& Cresswell, 2017; Stake, 2000).

\subsection{Study Group}

The study group of the research consists of 15 teachers who provide education and training services through distance education at the secondary level in a province in Turkey during the pandemic period. In order to use time and resources efficiently in determining the study group of the research, the easily accessible sampling method was used. Demographic information of the study group is presented in Table 1:

Table 1. Demographic characteristics of the study groups

\begin{tabular}{lllll}
\hline Participants & Gender & Age & Branch & Seniority \\
\hline F1 & Female & 32 & Math & $1-10$ years \\
F2 & Female & 34 & Computer Science & $1-10$ years \\
F3 & Female & 34 & Science & $1-10$ years \\
F4 & Female & 42 & Science & $11-20$ years \\
F5 & Female & 39 & Math & $11-20$ years \\
F6 & Female & 30 & Social Science & $1-10$ years \\
F7 & Female & 36 & Physical Science & $1-10$ years \\
F8 & Female & 41 & Turkish Science & $11-20$ years \\
M1 & Male & 36 & Math & $1-10$ years \\
M2 & Male & 38 & Physical Science & $11-20$ years \\
M3 & Male & 29 & History Science & $1-10$ years \\
M4 & Male & 45 & Computer Science & $11-20$ years \\
M5 & Male & 31 & Math & $1-10$ years \\
M6 & Male & 41 & Geography Science & $11-20$ years \\
M7 & Male & 39 & Foreign languages & $11-20$ years \\
\hline
\end{tabular}

\subsection{Data Collection Tools and Data Collection Method}

The most used data collection tool in qualitative research is interview (Yildirim \& Simsek, 2013). In this case study, a semi-structured interview form developed by the researcher was used. Before creating the questions in the interview form, studies examining the problems experienced in the distance education process were examined in the literature; and in this context, an item pool was created. 
Expert opinions were obtained from three faculty members working in the field of educational administration, and assessment and evaluation regarding the questions were included in the interview form. A preliminary interview was held with two teachers for clarity of the questions in the interview form and the questions were given their final form. Thus, the content validity of the questions was ensured.

In the semi-structured interview form, a total of six questions were asked to the participants, four of which were related to demographic characteristics. The interview form was sent to the teachers by email and responses were collected in writing via email. Teachers were asked for their feedback in the form within a week. The related questions are as follows:

1) Write a concept/metaphor about digital transformation in education during the pandemic period.

2) In the pandemic period, write the contribution of digital transformation in education in terms of your students.

3) Write the problems you have encountered in learning and teaching environments in the context of digital transformation in education during the pandemic period (in terms of students, families, technological tools etc.)

4) Write the affective developments you have observed in your students within the scope of digital transformation in education during the pandemic period.

5) Write the measurement and evaluation tools and technologies that you frequently used in the digital transformation in education during the pandemic period (online multiple-choice test, question and answer, digital activities and games etc.)

6) Finally, write your suggestions for improving the digital transformation process in education and eliminating existing problems during the pandemic period.

\section{Data Analysis}

The collected data were analysed by content analysis method. Content analysis is interpreting the answers given by the participants in a way that the reader can understand by bringing them together in certain categories (Yildırım \& Simsek, 2013). In the study, with the content analysis method, the data were first coded according to the meaning and then the codes are divided into categories. Then, the codes and categories created were tabulated with the frequency (f) values showing the frequency of the responses received from the teachers and were presented using direct quotations.

\subsection{Demographic Characteristics of the Study Groups}

When Table 1 was examined, on the demographic characteristics of the participants, it was determined that 8 of the 15 participants participating in the study were female and 7 were male. When the ages of the participants are examined, it is seen that they vary between 29 and 45 years. When the branches of study of the participants are examined, it is seen that there are four math, two computer sciences, two physical sciences, two science, one social science, one foreign language, one history science, one geography science and one Turkish science branches. Finally, when the seniority of the participants is examined, it is seen that eight teachers have a seniority of 1-10 years and seven teachers have a seniority of 11-20 years.

\section{Finding and Discussion}

The findings of the study are presented according to themes as shows from tables below.

Table 2. A concept/metaphor about digital transformation in education during the pandemic period

\begin{tabular}{lll}
\hline Metaphors & f & $\mathbf{\%}$ \\
\hline E-school/Zoom & 4 & 27.0 \\
Online Learning & 3 & 20.0 \\
Blended Learning & 2 & 13.3 \\
Distance Learning & 2 & 13.3 \\
Flipped Classroom & 1 & 6.6 \\
Online Certified Education & 1 & 6.6 \\
EBA TV (Education Information Network) & 1 & 6.6 \\
Digital Communication & 1 & 6.6 \\
Total & $\mathbf{1 5}$ & $\mathbf{1 0 0}$ \\
\hline
\end{tabular}


Teachers were asked to state a concept/metaphor about digital transformation in education during the pandemic period and in this context their answers were questioned. According to Table 2, the most frequently used metaphor by teachers was 'E-school/Zoom platform". This answer is followed by 'online education' with a high frequency. When the other answers are examined, it is seen that the answers vary from 'flipped classroom' to 'digital communication'. Alper (2020) has produced a case study dealing with distance education at the K-12 level during the pandemic process. In the research, it has been revealed that the online environment that is frequently used to manage the learning and teaching process is Zoom.

Table 3. In the pandemic period, the contribution of digital transformation in education in terms of students

\begin{tabular}{lll}
\hline Contribution in terms of students & f & $\mathbf{\%}$ \\
\hline Adopting with the digital process/era & 3 & 20.0 \\
Easy access to information & 2 & 19.4 \\
Digital Citizenship & 1 & 6.6 \\
Adaptation to new models in education & 1 & 6.6 \\
Permanent Learning & 1 & 6.6 \\
Collaborative Learning & 1 & 6.6 \\
Gain communication skills & 1 & 6.6 \\
Adopting Different Learning Techniques & 1 & 6.6 \\
Active participation in the lesson & 1 & 6.6 \\
Learning at your own pace & 1 & 6.6 \\
Student performance improvement & 1 & 6.6 \\
Repetitive use of knowledge with lecture recordings & 1 & 6.6 \\
Total & $\mathbf{1 5}$ & $\mathbf{1 0 0}$ \\
\hline
\end{tabular}

These findings are an evidence of what teachers adopt in their e-learning and the varieties in the pandemic process. In relation to this scope, Ozcan and Sarac (2020), in the pandemic process, investigated the role and competence of teachers in online distance education. As a result, these roles were collected under three titles: 'perceptions of communicator', 'social role' and 'pedagogical role'. In addition, it was found that the perception of the relevant role and competence did not differ according to the gender and competences were decreased.

When the answers given by the teachers to the question within the scope of the contribution of digital transformation in education for students during the pandemic period are examined, it can be determined that the response frequency is compatible with 'the digital process or era'. When the answers given by the teachers to the question within the scope of the contribution of digital transformation in education for students during the pandemic period are examined, it has been determined that the response frequency is compatible with "adopting with the digital process or era".

When interview form answers are examined;

- F1: With the coronavirus (COVID-19) pandemic, the importance of digitalisation in education was better understood by students. With this process, I think my students have adapted to the digital era. I can also list the competencies they have gained as cooperative learning in online learning environments, being responsible for their own learning and motivation towards the course. With these gains, I find it necessary to benefit from online teaching as well as face-to-face teaching after the pandemic period.

- M4: I think that my students adapt to new education models in the process. I still support the effectiveness of face-to-face education in the learning and teaching process but since I have seen my students achieve success with multimedia supported by online learning environments I also find different learning methods

- $\quad$ Mg6essfind the flexibility offered by distance education effective as an educator. I think that my students also benefit from this feature and feel more confident in their classroom environment and their participation in the course increases.

- F5: I think that the biggest privilege offered by digital media is easy access to information. My use of relevant video links, especially while lecturing, attracts the attention of my students and increases their concentration on the lesson. I can easily access and use these links via EBA TV.

When the different answers given by the participants are examined, it is emphasised that the motivation and participation level of the students can be increased by making use of the flexible and multi-environment offered by online environments, especially in the learning and teaching processes. With regard to the literature on the subject being examined, Ozdogan and Berkant (2020) and Aktas, Buyuktas, Gulle and Yildiz (2020) in their 
research studies received stakeholder opinions on education during the pandemic process. The university students also listed the following advantages: being independent of time and place, being able to watch the lessons many times, meeting the educational needs during the pandemic period, protection against the transmission of the disease and the importance of technology in education.

Table 4. The problems have encountered in learning and teaching environments in the context of digital transformation in education during the pandemic period in terms of teachers

\begin{tabular}{lll}
\hline Problems in terms of teachers & f & $\mathbf{\%}$ \\
\hline Deficiency of infrastructure & 5 & 33.6 \\
Technical problems & 3 & 20.0 \\
Deficiency of digital tools & 3 & 20.0 \\
Lack of content knowledge & 1 & 6.6 \\
Lack of guidelines & 1 & 6.6 \\
Low technology literacy & 1 & 6.6 \\
Problems in measurement and assessment & 1 & 6.6 \\
Total & $\mathbf{1 5}$ & $\mathbf{1 0 0}$ \\
\hline
\end{tabular}

When the opinions of the teachers were examined, it was determined that the biggest problem in the process is "the deficiency of infrastructure". Internet infrastructure problems, used online learning platform infrastructure deficiencies are included in this criterion.

When interview form answers are examined;

- F2: In the process, I see the deficiencies of infrastructure as a common problem of both teachers and students. Especially the interruptions due to the poor quality of the internet connection bring communication problems in addition lessons are interrupted.

- M7: I had problems as a tutorial before I started using the Zoom platform. I think there is a lack of guidelines for using the platform. This case a waste of time in terms of course flow.

- $\quad$ F4: I think the biggest problem in the process is technical problems. The biggest source of this problem is that students are missing hardware parts such as cameras and microphones. In particular, audio and video interruptions negatively affect the course flow.

With regard to the literature on the subject being examined, Avci and Akdeniz (2021), in their study, evaluated the COVID-19 pandemic and the problems encountered in the distance education process. In line with the opinions of the teachers, it has been stated that the deficiency of infrastructure and the problems experienced about the Internet are some of the biggest problems in the process. Onal and Kaya (2020), in their study, grouped the infrastructure problems in distance education into three categories: problems with the evaluation system, problems with the home environment and technical problems.

However to improve the process, there has been a natural increase in co-educational activities as the necessary facilities and infrastructures for distance education have begun to reach all segments of the society (Can \& Koroglu, 2020).

Table 5. The affective developments have observed in students within the scope of Digital Transformation in Education during the Pandemic Period

\begin{tabular}{lll}
\hline Affective developments have observed in students & $\mathbf{f}$ & $\mathbf{\%}$ \\
\hline Positive attitude towards learning & 3 & 20.2 \\
Socialization & 2 & 13.3 \\
Competition with each other/increasing success & 2 & 13.3 \\
Collaborative learning/activity & 2 & 13.3 \\
Learning with fun/ fun and creative educational activities & 2 & 13.3 \\
Active participate in discussions & 2 & 13.3 \\
Course satisfaction & 2 & 13.3 \\
Total & $\mathbf{1 5}$ & $\mathbf{1 0 0}$ \\
\hline
\end{tabular}


When the opinions of the teachers were examined, it was determined that the important affective development observed in students was "positive attitude towards learning". Looking at the other answers, it can be seen that the criteria varied from course satisfaction, active participate in discussions, socialisation etc.

When interview form answers are examined;

When interview form answers were examined, the following were obtained:

- M6: Since our students are social in online learning environments and like the feeling of being in competition with each other, preparing activities that they can apply together supports their learning by

- Movingufflted that my students got bored and distracted after a while in face-to-face education. On the other hand, with the multimedia I use on online learning platforms, I can keep the student's attention alive during the lesson. My students motivate the lesson; this also provides them to develop positive attitudes towards the lesson.

- M8: I think that the most important affective development is course satisfaction for both myself and my students. Considering that my students are described as Generation Z, I realise that they have adapted to the new digital process and attained course satisfaction.

- M5: I started using the Kahoot application in my class with the help of our computer teacher at our school. Zoom platform supports Kahoot app. I use the question-answer and brainstorming technique with Kahoot. At the end of the day, my students both learn by having fun and actively participate in the lessons.

With regard to the literature on the subject being examined, when the socialisation dimension is examined, the perceived sociability in the blended learning environment can be seen in both traditional classroom and higher in online classes. The reason for this is that blended learning combines both face-to-face communication provided by the traditional method and the conveniences of online learning (Rovai \& Jordan, 2004).

Table 6. The measurement and evaluation tools and technologies that you frequently used in the digital transformation in education during the pandemic period

\begin{tabular}{lll}
\hline The measurement and evaluation tools and technologies & f & $\mathbf{\%}$ \\
\hline Multiple choice test & 15 & 44.3 \\
Online course activities & 8 & 23.5 \\
Question and answer technique & 5 & 14.7 \\
Brainstorming technique & 4 & 11.7 \\
Process evaluation & 1 & 2.9 \\
Gamification & 1 & 2.9 \\
Total & $\mathbf{3 4}$ & $\mathbf{1 0 0}$ \\
\hline
\end{tabular}

When Table 6 is examined, it can be seen that all of the teachers stated that they use "multiple-choice tests" as an assessment tool. In addition to this assessment tool, it is noteworthy that online course activities, question-answer and brainstorming and process evaluation are used.

When the interview form answers were examined, the following were obtained:

- M1: We applied a multiple-choice test. In this context, we added the multiple-choice questions that students could do outside of the alive class time to the page, students answered the questions and sent them to us until the homework time expired.

- F3: I benefited from process evaluation in terms of measurement. During this process, I observed my students at the beginning and end of the semester. I determined the gains, I prepared the term final report.

- M8: I use gamification applications in my lessons and benefit from both question-answer and brainstorming techniques in the learning process. 
Table 7. The measurement and evaluation tools and technologies that you frequently used in the digital transformation in education during the pandemic period

\begin{tabular}{lll}
\hline Suggestions for improving the Digital Transformation process and problems & f & $\mathbf{\%}$ \\
\hline Elimination of infrastructure deficiencies & 15 & 40.5 \\
Assistance with material for students with financial problems & 7 & 18.9 \\
A systematic measurement and evaluation strategy & 6 & 16.2 \\
Regular and systematic planning as a ministry & 3 & 8.1 \\
Benefit from online learning environments after the pandemic process & 3 & 8.1 \\
Different and sudden decisions about the education process should not be taken. & 2 & 5.4 \\
Reporting on education and training activities and improving the process & 1 & 2.8 \\
Total & $\mathbf{3 7}$ & $\mathbf{1 0 0}$ \\
\hline
\end{tabular}

According to the table above, when teachers' opinions on improving the process and eliminating existing problems during the pandemic period are evaluated, the diversity of answers is remarkable. However, it is seen that the frequency is aimed at eliminating "elimination of infrastructure deficiencies". In addition to this, suggestions for assessment, evaluation and regular and systematic planning in education are among the other factors.

When the interview form answers were examined, the following were obtained:

- F7: I think that the most important role and responsibility for the improvement of the process rests with the Ministry of National Education. I am of the opinion that the sudden and different decisions taken during the process negatively affect all the stakeholders of education. At this point stakeholder opinions should be made mandatory when making decisions.

- M4: I benefited from the online teaching environments that came with the pandemic process. My students are motivated to the lesson with multimedia applications and increase their success. For this reason, I think that even if it is not completely online learning, online learning and platforms should be used after the pandemic process.

With regard to the studies in the literature on the subject being examined, Tedmem's Report (2020) included distance education and its problems during the pandemic period. As a result, the difficulty of developing students' professional skills with distance education has been mentioned. In the process, it was pointed out that as a solution proposal, studies should be carried out to develop the digital and pedagogical competencies required for distance education of teachers and students.

\section{Result and Suggestions}

This study aimed to determine the views of teachers on the transition to digital transformation in education during the pandemic process. The research was an example of a case study in the qualitative research. The study groups of the research consisted of 15 teachers who provided education and training services through distance education at the secondary level in a province in Turkey during the pandemic period. An interview form was prepared by the researcher to determine the teachers' views on the subject. In the interview form, a total of six questions were asked to the participants, four of which were related to the demographic characteristics. The interview form was sent to the teachers by email and responses were collected in writing via email.

The results of the research are summarised as follows: teachers were asked to state a concept/metaphor about digital transformation in education during the pandemic period and in this context their answers were questioned. The most frequently used metaphor by teachers was 'E-school/Zoom platform'. When the answers given by the teachers to the question within the scope of the contribution of digital transformation in education for students during the pandemic period were examined, it was determined that the response frequency is compatible with 'the digital process or era'. When the opinions of the teachers were examined, it was determined that the biggest problem in the process is 'the deficiency of infrastructure'. Internet infrastructure problems and using online learning platform infrastructure deficiencies were also included in this criterion. When the opinions of the teachers were examined, it was determined that the important affective development observed in students was 'positive attitude towards learning'. Looking at the other answers, it is seen that the criteria varied from course satisfaction, active participate in discussions, socialisation etc. All of the teachers stated that they used 'multiple-choice tests' as an assessment tool. When teachers' opinions on improving the process and eliminating existing problems during the pandemic period were evaluated, the diversity of answers was remarkable. However, it is seen that the frequency is aimed at eliminating 'the deficiencies of infrastructure'. 
Suggestions for future research and researchers are as follows:

- Since it was determined in the study that there are some infrastructure, technical, equipment and skill deficiencies in terms of stakeholders in the distance education process, various in-service trainings and infrastructure support can be provided by the Ministry of National Education officials.

- It can be ensured that educators are more willing to make sufficient efforts to eliminate the deficiencies arising from themselves and the infrastructure. In this sense, the motivation of teachers should be supported.

- In the research, effective opinions were obtained from the teachers about the process as a result of the interview data. The opinions expressed in this and future research should be taken into account and solutions for the problems experienced should be discussed.

In this study, the opinions of teachers who taught at the secondary school level on the subject were taken. In the future research, the scope can be expanded and the studies can be structured at different levels.

\section{References}

Aktas, O., Buyuktas, B., Gulle, M., \& Yıldız, M. (2020). Covıd-19 virüsünden kaynaklanan izolasyon günlerinde spor bilimleri öğrencilerinin uzaktan eğitime karşı tutumları. Sivas Cumhuriyet Üniversitesi Spor Bilimleri Dergisi, 1(1), 1-9. Retrieved from https://dergipark.org.tr/tr/pub/cussj/issue/55944/728866

Altun-Ekiz, M. (2020). Beden eğitimi ve spor yüksekokulu öğrencilerinin karantina dönemindeki uzaktan eğitim ile ilgili görüşleri (nitel bir araştırma). Spor ve Rekreasyon Araştırmaları Dergisi, 2(1), 1-13. Retrieved from https://dergipark.org.tr/tr/pub/srad/issue/54676/740217

Arı, A. G., \& Kanat, M. H. (2020). Covid-19 (Koronavirüs) Üzerine Öğretmen Adaylarının Görüşleri. Epidemic Diseases, Special Issue, 459-492. Retrieved from http://www.yyusbedergisi.com/dergiayrinti/covid-19-coronavirus-uzerine-ogretmen-adayi-gorusleri_1161

Avcı, F., \& Deniz, E. C. (2021). Koronavirüs (Covid-19) Salgını ve Uzaktan Eğitim Sürecinde Karşılaşılan Sorunlar Konusunda Öğretmenlerin Değerlendirmeleri. Uluslararası Sosyal Bilimler ve Eğitim Dergisi, 3(4), 117-154. Retrieved from https://dergipark.org.tr/tr/pub/usbed/issue/61198/910183

Başaran, M., Doğan, E., Karaoğlu, E., \& Şahin, E., (2020), Koronavirüs (Covid-19) Pandemi Sürecinin Getirisi Olan Uzaktan Eğitimin Etkililiği Üzerine Bir Çalışma. Academia Eğitim Araştırmaları Dergisi, 5(2), 368-397. Retrieved from https://dergipark.org.tr/tr/pub/egitim/issue/54643/753149

Batdal Karaduman, G., Akşak Ertaş, Z., \& Duran Baytar, S. (2021). Uzaktan eğitim yolu ile gerçekleştirilen matematik derslerine ilişkin öğretmen deneyimlerinin incelenmesi. International Primary Education Research Journal, 5(1), 1-17. Retrieved from https://dergipark.org.tr/tr/pub/iperj/issue/61098/855615

Bozkurt, A. (2019). From distance education to open and distance learning: A holistic evaluation of history, definitions, and theories. In S. Sisman-Ugur \& G. Kurubacak (Eds.), Handbook of Research on Learning in the Age of Transhumanism (pp. 252-273). Hershey, PA: IGI Global. https://doi.org/10.4018/978-1-5225-8431-5.ch016

Can, N., \& Koroglu, Y. (2020). COVID-19 Döneminde Yaygınlaşan Uzaktan Eğitimin Değerlendirilmesi ve Ĕgitim Emekçileri Açısından Incelenmesi. Retreived from http://bilimveaydinlanma.org/covid-19-doneminde-yayginlasan-uzaktan-egitimin-degerlendirilmesi-ve-egiti m-emekcileri-acisindan-incelenmesi/

Creswell, J. W., \& Creswell, J. D. (2017). Research design: Qualitative, quantitative, and mixed methods approaches. Sage publications.

Degges-White, S. (2020). Zoom Fatigue: Don't Let Video Meetings Zap Your Energy. Some 'cheats' to help you beat Zoom fatigue before it beats you. Psychology Today.

Duban, N., \& Sen, F. G. (2020). Sınıf öğretmeni adaylarının COVID-19 pandemi sürecine ilişkin görüşleri. Turkish Studies, 15(4), 357-376. https://doi.org/10.7827/TurkishStudies.43653

Hodges, C., Moore, S., Lockee, B., Trust, T., \& Bond, A. (2020). The difference between emergency remote teaching and online learning. EDUCAUSE Review, 3. Retrieved from https://er.educause.edu/articles/2020/3/the-difference-between-emergency-remote-teaching-and-online-lear ning

Karakuş, İ., \& Yelken, T. Y. (2020). Uzaktan eğitim alan üniversite öğrencilerinin sosyal bulunuşluk ile işlemsel uzaklıkları arasındaki ilişkinin incelenmesi. Kastamonu Eğitim Dergisi, 28(1), 186-201. 
https://doi.org/10.24106/kefdergi.3506

Karakus, N., Ucuzsatar, N., Karacaoglu, M. Ö., Esendemir, N., \& Bayraktar, D. (2020). Türkçe öğretmeni adaylarının uzaktan eğitime yönelik görüşleri. Rumelide Dil ve Edebiyat Araştırmalarl Dergisi, 19, 220-241. https://doi.org/10.29000/rumelide.752297

Kavuk, E., \& Demirtaş, H. (2021). COVID-19 Pandemisi Sürecinde Öğretmenlerin Uzaktan Eğitimde Yaşadığ1 Zorluklar. E-Uluslararası Pedandragoji Dergisi, 1(1), 55-73. https://doi.org/10.7051/e-ijpa.20L

Lin, C.-Y. (2020). Social reaction toward the 2019 novel coronavirus (COVID-19). Social Health and Behavior, 3(1), 1-2. https://doi.org/10.4103/SHB.SHB_11_20

Macit, A. (2020). Küresel Salgınların Tarihi ve Dünya Tarihsel Dönüşüm. İLEM Covıd-19 Soruşturma Dosyası.

Millî Eğitim Bakanlığı. (2020). Bakan Selçuk, koronavirüs'e karşı eğitim alanında alınan tedbirleri açıkladı. Retreived June 13, 2021, from https://www.meb.gov.tr/bakan-selcuk-koronaviruse-karsi-egitimalaninda-alinan-tedbirleriacikladi/haber/20 $497 / \mathrm{tr}$

Moore, M. G., \& Kearsley, G. (2012). Distance Education A System View Of Online Learning (3rd ed.). Belmont: Wadsworth.

Nicolai, S., \& Triplehorn, C. (2003). The Role of Education in Protecting Children in Conflict (Humanitarian Practice Network Paper 42). London: Overseas Development Institute.

O'Keefe, S., Roboti, P., Kwabena, B., Guanghu, Z., Hayden, S., Wei, Q, S., \& Stephen, H. (2020). Ipomoeassin-F inhibits the in vitro biogenesis of the SARS CoV-2 spike protein and its host cell membrane receptor. Ipom-F as a potential antiviral agent. https://doi.org/10.1101/2020.11.24.390039

Onaş, S., \& Kaya, U. H. G. G. (2020). Pandemi Sürecinde Uzaktan Hasta Takibi Uygulamalarında Tele-Tıp Ve Birinci Basamaktaki Yeri. Klinik Tip Aile Hekimliği, 12(3), 98-106. Retrieved from https://dergipark.org.tr/tr/pub/ktah/issue/59419/853656

Ozcan, B., \& Sarac, L. (2020). Covıd-19 pandemisi sürecinde öğretmen çevrimiçi uzaktan eğitim rol ve yeterlikleri: beden eğitimi öğretmenleri örneği. Milli Eğitim Dergisi, 459-475. https://doi.org/10.37669/milliegitim.787127

Ozdoğan, A. C., \& Berkant, H. G. (2020). COVID-19 pandemi dönemindeki uzaktan eğitime ilişkin paydaş görüşlerinin incelenmesi. Milli Eğitim Dergisi, 49(1), 13-43. https://doi.org/10.37669/milliegitim.788118

Rovai, A. P., \& Jordan, H. (2004). Blended Learning and Sense of Community: A Comparative Analysis with Traditional and Fully Online Graduate Courses. The International Review of Research in Open and Distributed Learning, 5(2). https://doi.org/10.19173/irrodl.v5i2.192

Sercemeli, M., \& Kurnaz, E. (2020). COVID-19 pandemi döneminde akademisyenlerin uzaktan eğitim ve uzaktan muhasebe eğitimine yönelik bakış açıları üzerine bir araştırma. Uluslararası Sosyal Bilimler Akademi Dergisi, 3, 262-288. Retrieved from https://dergipark.org.tr/tr/download/article-file/1163428

Sinclair, M. (2002). Planning Education in and After Emergencies. Paris: UNESCO International Institute for Educational Planning.

Sonmez, N. H. (2020). Covid 19 Bağlamında Uzaktan Eğitim ile İlgili Yapılan Bazı Çalışmaların Değerlendirilmesi. Journal of Current Research on Social Sciences (JoCReSS), 10(3), 625-642. https://doi.org/10.26579/jocress.396

Stake, R. E. (2000). Case studies. In N. K. Denzin \& Y. S. Lincoln (Eds.), Handbook of qualitative research (pp. 435-454). Thousand Oaks, CA: Sage Publications.

Tedmem Report. (2020). Retreived June 24, 2021, from https://tedmem.org/yayin/2020-egitim-degerlendirme-raporu

Telli, S. G., \& Altun, D. (2020). Coronavirüs ve çevrimiçi (online) eğitimin önlenemeyen yükselişi. Journal of University Studies, 3(1), 25-34. Retrieved from https://doi.org/10.32329/uad.711110

Toprak, M., Bayraktar, Y., \& Ozyilmaz, A. (2017). Regional analysis of impact of employment on inequality and growth in information and technology intensive sectors. Journal of Economics, Finance and Accounting (JEFA), 16, 207-214. https://doi.org/10.17261/Pressacademia.2017.451

Turkan, A., Leblebici, H., \& Som, İ. (2020). Opinions of teacher candidates on distance education implemented during the covid-19 pandemic period. European Journal of Education Studies, 7(11), 329-353. 
https://doi.org/10.46827/ejes.v7i11.3355

Ustun, C., \& Ozciftci, S. (2020). COVID-19 Pandemisinin Sosyal Yaşam ve Etik Düzlem Üzerine Etkileri: Bir Değerlendirme Çalışması. Anatolian Clinic Journal of Medical Sciences, 25(1), 142-153. https://doi.org/10.21673/anadoluklin.721864

Waddingham, R. (2020). COVID-19: How can we support each other (and ourselves)? Psychosis, 12(2), 101-105. https://doi.org/10.1080/17522439.2020.1759678

World Health Organization. (2020a). Novel Coronavirus (2019-nCoV): Situation report, 11. Retrieved from https://apps.who.int/iris/handle/10665/330776

World Health Organization. (2020b). WHO Director-General's Remarks at the Media Briefing on 2019-nCoV. Retreived June 22, 2021, from https://www.who.int/dg/speeches/detail/who-director-general-s-remarks-at-the-media-briefing-on-2019-nco v-on-11-february-2020

Yıldırım, A., \& Şimşek, H. (2013). Nitel Arastırma Yöntemleri. Ankara: Seçkin Yayıncılık, ISBN: 9750200071.

\section{Copyrights}

Copyright for this article is retained by the author, with first publication rights granted to the journal.

This is an open-access article distributed under the terms and conditions of the Creative Commons Attribution license (http://creativecommons.org/licenses/by/4.0/). 